\title{
Article \\ Modeling and Kinetics of Bioconversion and Chemical Properties (Wine and Vinegar) from Banana Pulp By-Products
}

\author{
Cyntia Akemi Tanaka 1, Flávia Imanishi Ruzon 1, Lucas Caldeirão Rodrigues Miranda 1, \\ Diego Galvan 1, Wilma Aparecida Spinosa ${ }^{1, *}$ and Raúl Jorge Hernan Castro-Gómez ${ }^{2}$ \\ 1 Agrarian Science Center, Department of Science and Technology Food, State University of Londrina (UEL), \\ Rodovia Celso Garcia Cid (PR 445), Km 380, Londrina 86057-970, Brazil; \\ cyntiatanaka@hotmail.com (C.A.T.); flaviaruzon@gmail.com (F.I.R.); lcmiranda@gmail.com (L.C.R.M.); \\ diegogalvann@hotmail.com (D.G.) \\ 2 Master of Science and Technology of Milk, North University of Paraná (UNOPAR), Rua Marselha, \\ 183 - Parque Residencial João Piza, Londrina 86041-140, Brazil; rcastrog@yahoo.com \\ * Correspondence: wilma.spinosa@uel.br, Tel. +55 (43) 3371-4585; Fax: +55 (43) 3328-4440
}

\begin{abstract}
The alcoholic fermentation process with agitation/static, followed by the acetic fermentation submerged in banana was evaluated. Kinetics parameters of alcoholic fermentation for the maximum ethanol/glycerol metabolites in agitated process was 29 and $27 \mathrm{~h}$, and in static 47 and $45 \mathrm{~h}$, respectively. For acetic fermentation, the kinetics parameters were medium time of $39.9 \mathrm{~h}$, acetic acid yield of $53.1 \%$ and acetic acid productivity of $0.216 \mathrm{~g} / \mathrm{Lh}$. Wines from agitated/static process presented 5.73 and $6.81 \%(\mathrm{v} / \mathrm{v})$ of alcohol content, respectively. Wine obtained by the static process presented higher concentrations of volatile compounds. The vinegar showed $49.2 \mathrm{~g} / \mathrm{L}$ of acetic acid and the esters concentrations were higher than in wine. The wine and vinegar minerals were consistent with amount observed in the pulp, with an increase in sulphur concentration after alcoholic fermentation and decrease after acetic fermentation. Products showed chemical and composition of sensory and nutritional interest.
\end{abstract}

Keywords: acetic fermentation; alcoholic fermentation; submerged process; volatile compounds; acetic bacteria

\section{Introduction}

Banana (Musa spp.) is a general term embracing a number of species or hybrids of the genus Musa from the Musaceae family. It is one of the most cultivated and consumed fruit, in the world, being produced mainly in tropical countries [1]. Considerable part $(40-50 \%)$ of world banana production is discarded due to inadequate handling or storage. These residues can potentially be used for industrial purposes, reducing post harvest losses, diversifying production and adding value to the product [2].

Fermentation is a viable technique for developing new products. Alcoholic fermentation involves an anaerobic reaction that converts fermentable sugars into alcohol, carbon dioxide, biomass and secondary products, such as organic acids, higher alcohols, aldehydes, esters, glycerol and methanol, which are responsible for the essential sensory attributes, such as aroma and flavor. Saccharomyces cerevisiae is the most commonly yeast used [3]. The fermentation efficiency and the final product quality are closely linked to the performance of yeast in the wort [2].

Vinegar is used by many cultures and consumed by all social classes, as a condiment, flavouring, preservative, cleaning agent [4]. Vinegar production consists of two consecutive steps: alcoholic fermentation, by yeast action, which converts sugars into ethanol; followed by acetic fermentation, which is the oxidation of alcohol into acetic acid, by acetic bacteria in an aerobic medium with the formation of other secondary compounds [5]. Fruit vinegars are considered to be better in sensory 
and nutritional quality when compared to other vinegars, since they contain many substances, such as vitamins and organic acids [6].

According to Siqueira et al. [7], intensive researches on kinetics parameters have been carried out in order to obtain more efficient fermentative organisms, low cost substrates and better fermentation conditions. The transposition of a laboratory experiment into industrial scale is feasible when one knows the kinetics of the process. Therefore, the aim of this study was to first obtain a wine and then a vinegar from the pulp of hydrolyzed banana cv. Prata, obtaining kinetics parameters from alcoholic fermentation process with agitation and static (ethanol and glycerol), and from submerged acetic fermentation (acetic acid). The products were characterized by their physicochemical profile, mineral content and volatile compounds.

\section{Material and methods}

\subsection{Materials}

Bananas cv. Prata (Musa spp.), were purchased from local shops of Cornelio Procopio, Parana Brazil. Pectinex ${ }^{\circledR}$ Ultra SP-L enzyme (Lot KRN05639, Novozymes ${ }^{\circledR}$, Denmark) is a polygalacturonase with an enzymatic activity of 3800 PGNU/mL. The lyophilized cells of S. cerevisiae ATCC 2345 was provided by Fundação Tropical de Pesquisa e Tecnologia Andre Tosello (Campinas, Sao Paulo - Brazil), and the Acetobacter sp. bacteria used in submerged acetic fermentation, was obtained from Tecnologia em Saúde Indústria de Alimentos (Assis, Sao Paulo - Brazil).

\subsection{Banana pulp Processing}

Bananas at maturation stage 8, according to Wills scale [8], selected by their health and absence of bruises, were cleaned by immersion in active chlorine solution (100 $\mathrm{mg} / \mathrm{L})$ for $15 \mathrm{~min}$. Subsequentely, the fruits were rinsed and peeled manually. This pulp yield of fruits was carried out gravimetrically in a semi-analytical balance (AS5000C, Marconi ${ }^{\circledR}$, Brazil) expressed in percentage (\% $\mathrm{w} / \mathrm{w}$ ). The pulp was ground in a household blender (Walita ${ }^{\circledR}$, Brazil) for $5 \mathrm{~min}$ and packaged in plastic containers, kept at a temperature of $-20^{\circ} \mathrm{C}$.

\subsection{Physicochemical characterization of pulp}

The analysis of titratable acidity, ash, lipids, pH (pHmeter PG2000, Gehaka ${ }^{\circledR}$, Brazil), moisture, proteins, total soluble solids (Refractometer - RM40, Mettler Toledo ${ }^{\circledR}$, USA) were performed according to AOAC [9]. Total sugars were analyzed in a spectrophotometer (Genesis 6, Thermo Electron Corporation ${ }^{\circledR}$, USA) at $490 \mathrm{~nm}$, as described by DuBois et al. [10]. Carbohydrate content was obtained by the difference, in percentage, of protein, lipids and ash content to the total, in dry matter. Minerals were determined in an Inductively Coupled Plasma Optical Emission Spectrometer (ICP/OES, Optima 8300 - Perkin Elmer ${ }^{\circledR}$, USA), according to APHA [11].

\subsection{Enzymatic hydrolysis of pulp}

The pulp was thawed and the total soluble solids content was adjusted with distilled water to $15^{\circ} \mathrm{Bx}$. Then, the pulp was hydrolysed by the addition of $0.025 \mathrm{~g}$ of polygalacturonase enzyme to every $100 \mathrm{~g}$ of banana pulp, and kept at room temperature for $2 \mathrm{~h}$. After hydrolysis, the enzyme was inactivated by heating at $121^{\circ} \mathrm{C}$ for $15 \mathrm{~min}$ and then, cooled in an ice bath [2]

\subsection{Inoculum preparation}

Lyophilized cells of S. cerevisiae ATCC 2345, were rehydrated in sterile distilled water, then they were transferred to Yeast Mannitol Broth (YMB - yeast extract $3.0 \mathrm{~g} / \mathrm{L}$, malt extract $3.0 \mathrm{~g} / \mathrm{L}$, bacto peptone $5.0 \mathrm{~g} / \mathrm{L}$, dextrose $10.0 \mathrm{~g} / \mathrm{L}$ ), and incubated in an orbital shaker with agitation and temperature control (CT-712 R, Cientec ${ }^{\circledR}$, Brazil), at $120 \mathrm{rpm}, 30^{\circ} \mathrm{C}$ for $24 \mathrm{~h}$. The hydrolyzed banana was diluted with distilled water in aliquots of $4,6,8,10,12$ and $14{ }^{\circ} \mathrm{Bx}$, to which nutrients were added according to Spinosa et al. [3]. After $24 \mathrm{~h}, 10 \%(\mathrm{v} / \mathrm{v})$ of the YMB containing the S. cerevisiae were transferred to 
the hydrolyzed banana at $4{ }^{\circ} \mathrm{Bx}$. They were incubated in an orbital shaker at $120 \mathrm{rpm}, 30^{\circ} \mathrm{C}$ for $24 \mathrm{~h}$. The previous sequence was repeated with the others hydrolyzed pulps $\left(6,8,10,12\right.$ and $\left.14{ }^{\circ} \mathrm{Bx}\right)$ to obtain a sufficient amount of the inoculum ( $25 \% \mathrm{v} / \mathrm{v}$ of the total), containing $8 \log$ viable cells $/ \mathrm{mL}$, and them transfered it to the hydrolyzed pulp at $15^{\circ} \mathrm{Bx}$. The counting of viable cells $/ \mathrm{mL}$ was carried out in a Neubauer chamber [3] and the biomass was determined according to Alvarenga et al. [2].

\subsection{Alcoholic fermentation with agitation and static process}

The alcoholic fermentation process, were conducted in a bioreactor (Rubia Basic, Biofoco ${ }^{\circledR}$, Brazil), with agitation at $600 \mathrm{rpm}$ and the static process with total and available capacity of $6 \mathrm{~L}$ and 4 $\mathrm{L}$, respectively. The equipment was equipped with agitation, aeration, temperature, and $\mathrm{pH}$ controls and in both cases, the bioreactor was filled with hydrolyzed wort at $15^{\circ} \mathrm{Bx}$ and suspension of $S$. cerevisiae cells $(25 \% \mathrm{v} / \mathrm{v})$. Fermentations were conducted at $30^{\circ} \mathrm{C}$ and monitored for a 71 -hour-period, when $\mathrm{CO}_{2}$ bubbles formation ceased and it was considered that the wine was obtained. Samples were taken at $2 \mathrm{~h}$ intervals throughout the fermentation process, totaling 37 sampling points. The samples were then centrifuged at $10.000 \mathrm{rpm}$, at $10{ }^{\circ} \mathrm{C}$, for $10 \mathrm{~min}$ (Centrifuge $5804 \mathrm{R}$, Eppendorf ${ }^{\circledR} \mathrm{AG}$, Germany) and the number of cells was determined immediately and the supernatants were kept at $20^{\circ} \mathrm{C}$ for later determination of kinetics parameters.

\subsection{Alcoholic fermentation monitoring analysis}

The alcoholic fermentation process was monitored by the parameters of titratable acidity, total soluble solids, total sugars, $\mathrm{pH}$, viable cells/mL and biomass. Alcohol content was determined in a digital density meter (DDM 2911, Rudolph Research Analytical ${ }^{\circledR}$, USA) [12]. Alcohol concentration was measured using predefined conversion tables at $20^{\circ} \mathrm{C}$, and then converted to alcohol content in mass per volume. Glycerol content was determined by enzymatic colorimetric triglycerides kit (Lot 40930041, Bioliquid ${ }^{\circledR}$, Laborclin ${ }^{\circledast}$, Brazil) and the absorbance values were measured in a spectrophotometer at $510 \mathrm{~nm}$ (Genesis 6, Thermo Electron Corporation ${ }^{\circledR}$, USA) [13].

\subsection{Kinetics parameters of alcoholic fermentation}

The kinetics parameters of alcoholic fermentation calculated for ethanol and glycerol metabolites were: ethanol/glycerol productivity $-\mathrm{P}_{\mathrm{p}}=\left[\left(\mathrm{P}_{\mathrm{f}}-\mathrm{P}_{0}\right) / t\right]$, biomass productivity $-\mathrm{P}_{\mathrm{x}}=\left[\left(\mathrm{X}_{\mathrm{f}}-\mathrm{X}_{0}\right) / t\right]$, $\mathrm{g} / \mathrm{Lh}$; ethanol yield on initial sugar $-\mathrm{Y}_{1 \text {-ethanol }}=\left\{\left[\left(\mathrm{P}_{\mathrm{f}}-\mathrm{P}_{0}\right) /\left(\mathrm{S}_{0} * 0.511\right)\right] * 100\right\}$ and consumed sugar $-\mathrm{Y}_{2 \text {-ethanol }}=\left\{\left[\left(\mathrm{P}_{\mathrm{f}}-\mathrm{P}_{0}\right) /\left(\mathrm{S}_{0}-\mathrm{S}_{\mathrm{f}}\right) * 0.511\right] * 100\right\}$, glycerol yield on initial ethanol $\mathrm{Y}_{1 \text {-glycerol }}=\left\{\left[\left(\mathrm{P}_{\mathrm{f}}-\mathrm{P}_{0}\right)_{\text {glycerol }} /\left(\mathrm{P}_{0}\right.\right.\right.$ ethanol $\left.\left.\left.* 0.088\right)\right] * 100\right\}$ and produced ethanol $-\mathrm{Y}_{2 \text {-glycerol }}=$ $\left\{\left[\left(\mathrm{P}_{\mathrm{f}}-\mathrm{P}_{0}\right)_{\text {glycerol }} /\left[\left(\mathrm{P}_{0}-\mathrm{P}_{\mathrm{f}}\right)_{\text {ethanol }} * 0.088\right]\right] * 100\right\}, \%$; yield coefficient of biomass on sugar $-\mathrm{Y}_{\mathrm{x} / \mathrm{s}}=$ $\left\{\left[\left(\mathrm{X}_{\mathrm{f}}-\mathrm{X}_{0}\right) /\left(\mathrm{S}_{0}-\mathrm{S}_{\mathrm{f}}\right)\right] * 100\right\}$, yield coefficient of ethanol/glycerol on sugar/ethanol $-\mathrm{Y}_{\mathrm{p} / \mathrm{s}}=$ $\left\{\left[\left(\mathrm{P}_{\mathrm{f}}-\mathrm{P}_{0}\right) /\left(\mathrm{S}_{0}-\mathrm{S}_{\mathrm{f}}\right)\right] * 100\right\}$ and yield coefficient of ethanol/glycerol on biomass $-\mathrm{Y}_{\mathrm{p} / \mathrm{x}}=$ $\left\{\left[\left(\mathrm{X}_{\mathrm{f}}-\mathrm{X}_{0}\right) /\left(\mathrm{P}_{\mathrm{f}}-\mathrm{P}_{0}\right)\right] * 100\right\}, \%$; biomass production rate $-\mathrm{r}_{\mathrm{X}}=\frac{\mathrm{dX}}{\mathrm{dt}}$, sugar consumption rate $-\mathrm{r}_{\mathrm{s}}=$ $\frac{\mathrm{dS}}{\mathrm{dt}}$ and ethanol/glycerol production rate $-\mathrm{r}_{\mathrm{p}}=\frac{\mathrm{dP}}{\mathrm{dt}}$, g/Lh; specific biomass production rate $-\mu_{\mathrm{x}}=$ $\left(\frac{1}{\mathrm{x}}\right) *\left(\frac{\mathrm{dx}}{\mathrm{dt}}\right)$, specific sugar consumption rate $-\mu_{\mathrm{s}}=\left(\frac{1}{\mathrm{x}}\right) *\left(-\frac{\mathrm{d} S}{\mathrm{dt}}\right)$ and specific ethanol/glycerol production rate $-\mu_{\mathrm{p}}=\left(\frac{1}{\mathrm{x}}\right) *\left(\frac{\mathrm{dP}}{\mathrm{dt}}\right), \mathrm{h}^{-1} . \mathrm{P}, \mathrm{X}$ and $\mathrm{S}$ represent ethanol or glycerol, biomass and sugar, respectively; the subscribed item 0 and $\mathrm{f}$ represent the initial and final concentration in $\mathrm{g} / \mathrm{L}$, respectively. The value of 0.511 was considered the stoichiometric yield in the conversion of sugar to ethanol and 0.088 was the stoichiometric yield the ethanol and glycerol [3]. Experimental data were adjusted and compared to the mathematical model (polynomial equation of third order) using the Matlab $^{\circledR}$ R2010a software. 


\subsection{Vinegar inoculum}

Acetobacter sp. bacteria were used, in the presence of air, for the acetic fermentation. Such bacteria were previously selected, in a spontaneous way depending on the acidity of the medium in which they were maintained [4].

\subsection{Acetic fermentation}

The wine (alcohol content of $72 \mathrm{~g} / \mathrm{L}$ at $20^{\circ} \mathrm{C}$ and $\mathrm{pH}$ of 4.0) obtained on the static process was submited to a submerged acetic fermentation, in a bioreactor (Rubia Basic, Biofoco ${ }^{\circledR}$, Brazil) at $30^{\circ} \mathrm{C}$, $500 \mathrm{rpm}$ agitation, aeration flow of $1 \mathrm{~L} / \mathrm{min}$ and $0.25 \mathrm{vvm}$ (air volume per volume of culture medium per minute).

\subsection{Submerged acetic fermentation monitoring analysis}

During 16 days, aliquots were taken with $0.2 \%$ trypan blue dye. Titratable acidity, $\mathrm{pH}$ and alcohol content, were determined. The viable and non viable acetic acid bacteria were counted in a Neubauer chamber and the results were expressed as cells $/ \mathrm{mL}$. Titratable acidity and alcohol content analyses were used as parameters to the loading and unloading of the 7 fermentative cycles. The process of feeding and discharge of fermentor was: total concentration calculated as the sum of alcohol content plus titratable acidity concentration [4]. The initial total concentration was $8.0 \%(\mathrm{~m} / \mathrm{v})$.

\subsection{Kinetics parameters of acetic fermentation}

The $\mathrm{R}_{\mathrm{GK}}$ yield $-\mathrm{R}_{\mathrm{GK}}=\left\{\left[\left(\mathrm{GK}_{\mathrm{final}}\right) /\left(\mathrm{GK}_{\text {inicial }}\right)\right] * 100\right\}$, conversion of alcohol to acetic acid, \%, was calculated based on the total concentration (Bortolini et al., 2001). The acetic acid yield $-\eta_{\text {aa }}=$ $\left\{\left[(\mathrm{AA}(\mathrm{g} / \mathrm{L}) * 0.77) /\left(\mathrm{P}_{0}(\mathrm{~g} / \mathrm{L})\right)\right] * 100\right\}, \%$, was obtained by the ratio mass of acetic acid produced (AA) in $\mathrm{g} / \mathrm{L}$ and initial alcohol content $\left(\mathrm{P}_{0}\right)$ in $\mathrm{g} / \mathrm{L}$. The value of 0.77 was the stoichiometric yield in the conversion of ethanol to acetic acid. The acetic acid productivity - $\mathrm{P}_{\mathrm{aa}}=$ $\left\{\left[\left(\mathrm{V}_{\mathrm{aa}}(\mathrm{L}) * \mathrm{AA}(\mathrm{g} / \mathrm{L})\right) /\left(\mathrm{V}_{\text {total }}(\mathrm{L}) * \mathrm{t}(\mathrm{h})\right)\right]\right\}, \mathrm{g} / \mathrm{Lh}$, was calculated considering $\mathrm{V}_{\text {aa }}$ as volume $(\mathrm{L})$ of acetic acid produced; AA as the mass of acetic acid in volume produced in $\mathrm{g} / \mathrm{L}$; $\mathrm{t}$ as the fermentation time of the cycle (h); and $\mathrm{V}_{\text {total }}$ as bioreactor volume, in this case $6 \mathrm{~L}$ [4].

\subsection{Final treatment of wines and vinegar}

At the end of the alcoholic or acetic fermentation, the crude wines or vinegar were centrifuged (to remove any suspended material) and, subsequently, bottled in glass bottles.

\subsection{Characterization of wines and vinegar}

The analysis of titratable acidity, volatile acidity, fixed acidity, ash, alcohol content at $20{ }^{\circ} \mathrm{C}, \mathrm{pH}$, total soluble solids, total and reduced dry extract were performed according to AOAC [9]. Total sugars were performed according to DuBois et al. [10]; glycerol [13] and mineral compounds were determined in ICP/OES. Volatile compounds were detected by gas chromatography (QP-2010 Plus, Shimadzu${ }^{\circledR}$, Japan), equipped with Stabilwax-DA ${ }^{\circledR}$ column (Crossbond carbowax polyethylene glycol, $30 \mathrm{~m} \times 0.18 \mathrm{~mm} \times 0.18 \mu \mathrm{m}$ film thickness - Restek ${ }^{\circledR}$, USA) and a Flame Ionisation Detector (GC/FID) following conditions described by Bortoletto and Alcarde [14]. Acetic acid was determined by volumetric neutralization of the sample after distillation by drag steam [15].

\section{Results and discussion}

\subsection{Characterization of banana pulp}

The ratio pulp/peel at banana used was 2.48 and the pulp yield was $71.28 \%$. Its physicochemical characterization is presented on Table 1. Carbohydrates in the form of total sugars are the main components of banana pulp and they are fermentable. The pulp also contained small amounts of ashes, lipids, proteins and a low acidity, which favors the fermentation process. 
Table 1. Physicochemical characteristics of banana pulp, alcoholic and acetic fermented.

\begin{tabular}{ccccc}
\hline Components $^{\mathrm{a}}$ & Pulp & Wine - Agitation & Wine - Static & Vinegar \\
\hline Fixed acidity $(\mathrm{g} / \mathrm{L})$ & - & $2.80( \pm 0.06)$ & $3.20( \pm 0.10)$ & $17.90( \pm 0.05)$ \\
Titratable acidity $(\mathrm{g} / \mathrm{L})$ & $3.70( \pm 0.25)$ & $3.90( \pm 0.06)$ & $4.40( \pm 0.01)$ & $44.10( \pm 0.05)$ \\
Volatile acidity $(\mathrm{g} / \mathrm{L})$ & - & $1.10( \pm 0.06)$ & $1.20( \pm 0.00)$ & $26.20( \pm 0.00)$ \\
Total sugars $(\mathrm{g} / \mathrm{L})$ & $83.95( \pm 0.81)$ & $12.68( \pm 0.55)$ & $7.29( \pm 0.50)$ & $10.27( \pm 0.26)$ \\
Ash $(\mathrm{g} / \mathrm{g} \text { or } \mathrm{g} / \mathrm{L})^{\mathrm{b}}$ & $3.01( \pm 0.05)$ & $11.25( \pm 0.05)$ & $8.63( \pm 0.38)$ & $3.73( \pm 0.06)$ \\
Total dry extract $(\mathrm{g} / \mathrm{L})$ & - & $38.17( \pm 0.51)$ & $28.20( \pm 0.26)$ & $21.23( \pm 0.42)$ \\
Reduced dry extract $(\mathrm{g} / \mathrm{L})$ & - & $25.49( \pm 0.53)$ & $20.91( \pm 0.38)$ & $10.96( \pm 0.11)$ \\
Alcohol content at $20{ }^{\circ} \mathrm{C}(\mathrm{v} / \mathrm{v})$ & - & $5.73( \pm 0.00)$ & $6.81( \pm 0.00)$ & $0.00( \pm 0.00)$ \\
pH & $4.86( \pm 0.00)$ & $4.00( \pm 0.02)$ & $4.00( \pm 0.01)$ & $3.21( \pm 0.01)$ \\
Total soluble solids $(\mathrm{g} / \mathrm{L})$ & $243.00( \pm 1.00)$ & $54.70( \pm 0.58)$ & $55.00( \pm 0.00)$ & - \\
Carbohydrate $(\mathrm{g} / \mathrm{g})^{\mathrm{b}}$ & $93.20( \pm 0.13)$ & - & - & - \\
Lipids $(\mathrm{g} / \mathrm{g})^{\mathrm{b}}$ & $1.38( \pm 0.03)$ & - & - & - \\
Protein $(\mathrm{g} / \mathrm{g})^{\mathrm{b}}$ & $2.41( \pm 0.01)$ & $0.00( \pm 0.00)$ & - & - \\
Crude fiber $(\mathrm{g} / \mathrm{g})^{\mathrm{b}}$ & & - & -
\end{tabular}

a triplicate values. $\mathrm{b} \%$ Dry basis.

Minerals found in the pulp are shown in Table 2. They were similar to those reported by Wall [16] for banana (Musa sp.) from Hawaii. Mineral composition affects the performance of alcoholic fermentation. The importance of each mineral in the fermentation process can be seen in Spinosa et al. [3].

Table 2. Mineral content of banana pulp, alcoholic and acetic fermented.

\begin{tabular}{ccccc}
\hline Minerals $(\mathbf{m g} / \mathrm{L})^{\mathrm{a}}$ & Pulp & Wine - Agitation & Wine - Static & Vinegar \\
\hline $\mathrm{P}$ & $195.00( \pm 1.21)$ & $139.95( \pm 1.86)$ & $140.90( \pm 1.56)$ & $381.85( \pm 2.82)$ \\
$\mathrm{K}$ & $3,051.50( \pm 8.56)$ & $1,611.00( \pm 6.34)$ & $2,253.00( \pm 5.77)$ & $1,544.00( \pm 5.75)$ \\
$\mathrm{Ca}$ & $46.64( \pm 0.41)$ & $34.60( \pm 0.50)$ & $37.23( \pm 0.43)$ & $24.90( \pm 0.39)$ \\
$\mathrm{Mg}$ & $303.60( \pm 1.63)$ & $188.00( \pm 1.14)$ & $150.30( \pm 0.91)$ & $144.65( \pm 0.93)$ \\
$\mathrm{S}$ & $55.87( \pm 0.62)$ & $154.80( \pm 1.72)$ & $186.25( \pm 2.31)$ & $68.78( \pm 1.46)$ \\
$\mathrm{Na}$ & $26.99( \pm 1.87)$ & $25.35( \pm 1.98)$ & $29.26( \pm 1.82)$ & $8.07( \pm 0.09)$ \\
$\mathrm{B}$ & $1.09( \pm 0.01)$ & $0.78( \pm 0.02)$ & $1.08( \pm 0.02)$ & $0.59( \pm 0.01)$ \\
$\mathrm{Cu}$ & $1.68( \pm 0.02)$ & $1.71( \pm 0.03)$ & $1.67( \pm 0.02)$ & $0.13( \pm 0.01)$ \\
$\mathrm{Fe}$ & $2.72( \pm 0.05)$ & $3.05( \pm 0.02)$ & $3.03( \pm 0.03)$ & $1.02( \pm 0.02)$ \\
$\mathrm{Mn}$ & $1.70( \pm 0.06)$ & $2.68( \pm 0.09)$ & $3.02( \pm 0.02)$ & $3.09( \pm 0.03)$ \\
$\mathrm{Zn}$ & $1.79( \pm 0.03)$ & $2.85( \pm 0.02)$ & $2.65( \pm 0.03)$ & $1.73( \pm 0.02)$ \\
$\mathrm{Al}$ & $0.93( \pm 0.01)$ & $1.52( \pm 0.02)$ & $3.06( \pm 0.02)$ & $0.34( \pm 0.01)$ \\
$\mathrm{Mo}$ & $0.01( \pm 0.01)$ & $0.03( \pm 0.01)$ & $0.01( \pm 0.01)$ & $0.01( \pm 0.01)$ \\
$\mathrm{Ni}$ & $0.12( \pm 0.03)$ & $0.09( \pm 0.01)$ & $0.09( \pm 0.02)$ & $0.23( \pm 0.01)$ \\
$\mathrm{Si}$ & $18.44( \pm 1.90)$ & $19.18( \pm 2.32)$ & $24.82( \pm 2.12)$ & $17.94( \pm 1.89)$ \\
\hline
\end{tabular}




\subsection{Monitoring the alcoholic fermentation}

The behaviour of S. cerevisiae ATCC 2345 yeast was evaluated during the different fermentation systems, emphasizing the maximum values of ethanol and glycerol production (Fig. 1). The experiments were designed with a sufficient number of cells and sugar concentration for the $S$. cerevisiae fermentative route.

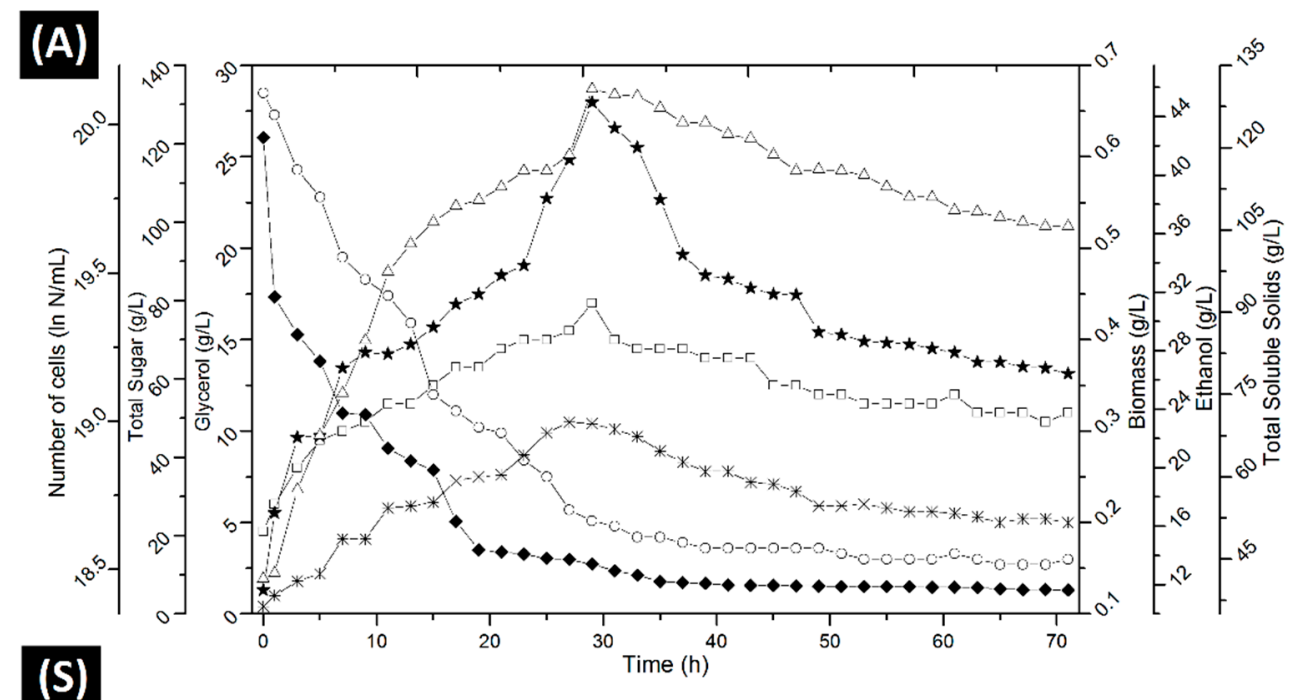

(S)

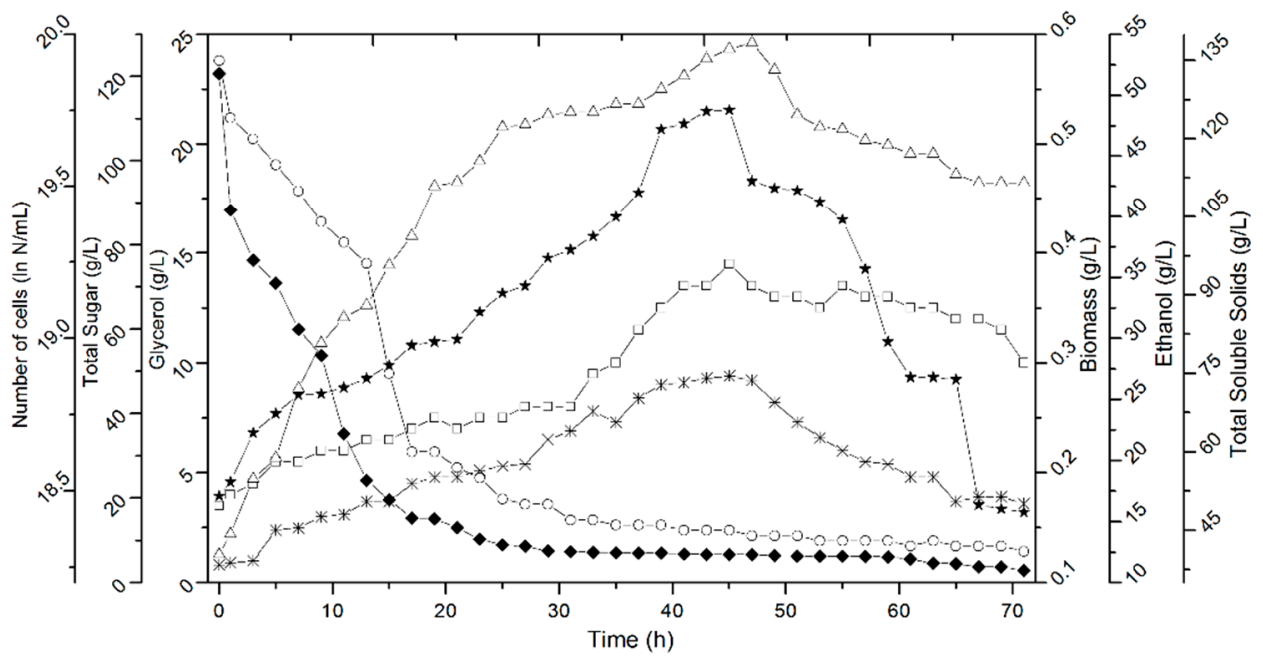

Fig. 1. Fermentation of agitated and static processes: $(\star)$ number of cells; $(\square)$ biomass production; $(\diamond)$ total sugars consumption; $(\Delta)$ ethanol production; $(*)$ glycerol production; and $(\circ)$ total soluble solids variation versus time $(\mathrm{h})$.

The initial number of cells in both processes was approximately $18.5 \ln \mathrm{N} / \mathrm{mL}$. Biomass was 0.19 $\mathrm{g} / \mathrm{L}$ for the agitated, and $0.17 \mathrm{~g} / \mathrm{L}$ for the static process (Fig. 1). The initial substrate concentration for total sugars was $121 \mathrm{~g} / \mathrm{L}$ for both processes. A reduction of approximately $90 \%$ of total sugars (12.7 $\mathrm{g} / \mathrm{L})$ was observed during the 0-29 $\mathrm{h}$ interval in the agitated process, while biomass doubled. A reduction of almost $95 \%$ of total sugars $(6.7 \mathrm{~g} / \mathrm{L})$ was observed in the $0-45 \mathrm{~h}$ interval in the static fermentation, and the biomass doubled. After these intervals, there was a decrease of about $25 \%$ in the biomass ( $0.3 \mathrm{~g} / \mathrm{L}$ after $71 \mathrm{~h}$ of fermentation) when compared to the maximum biomass found for both processes. This was most likely due to the combination of the low concentration of substrate and the high concentration of alcohol. The medium composition is one of the most important among many factors affecting yeast fermentation ability, as well as the fermentation efficiency and the final product quality. These are closely linked to the affinity between yeast and substrate [1].

The maximum conversion of sugar into ethanol was obtained after $29 \mathrm{~h}(45.9 \mathrm{~g} / \mathrm{L})$ and $47 \mathrm{~h}(54.3$ $\mathrm{g} / \mathrm{L}$ ) for agitated and static processes, respectively (Fig. 1). Ethanol concentration decreased in both 
cases after $71 \mathrm{~h}$ (36.5 and $42.8 \mathrm{~g} / \mathrm{L}$ for agitated and static processes, respectively). In discontinuous processes, such as process with agitation and static, high sugars concentrations may result in a repression, known as Crabtree Effect, in which the enzymes of microbian respiration are inhibited and the ethanol production increases. S. cerevisiae is an anaerobic facultative microorganism and fermentation is its preferential metabolic route, even in the presence of oxygen. On the other hand, $S$. cerevisiae is able to oxidize ethanol, producing carbon dioxide and water, which explains its decline during the assessed period.

The amount of actual ethanol produced in the agitated and static fermentations was less than was expected (62.13 and $61.67 \mathrm{~g} / \mathrm{L}$, respectively). Some data explain why this happens: about $5 \%$ of total sugars are converted into secondary products; $2.5 \%$ are consumed by the yeast, as a carbon source, and $0.5 \%$ is non-fermentable residual sugar. About $4 \%$ of sugars metabolized by yeast are converted into glycerol, a simple alcohol produced by S. cerevisiae during the fermentation of glucose to alcohol, in order to keep the redox balance. However, the excess of glycerol may reduce the ethanol yield of the wine.

Maximum glycerol production in agitated and static processes occurred after 27 and $45 \mathrm{~h}$ (Fig. 1), with 10.5 and $9.4 \mathrm{~g} / \mathrm{L}$, respectively. Factors such as temperature, aeration, sugar concentration and osmotic stress affect the glycerol yield [2, 7]. According to Wang et al. [17], more sugar is converted into alcohol and ethyl acetate in processes with low levels of aeration, thus, decreasing glycerol production significantly, as seen in the static process. Products obtained in agitated and static processes showed alcohol content of 5.73 and $6.81 \mathrm{~g} / \mathrm{L}$; ethyl acetate of 18.1 and $23.2 \mathrm{mg} / \mathrm{L}$; and glycerol of 10.4 and $9.2 \mathrm{~g} / \mathrm{L}$, respectively.

Total sugars consumption data corroborate the total soluble solids variation data as a function of fermentation time. There was a $60 \%$ decrease in total soluble solids with $29 \mathrm{~h}$ during the fermentation in the agitated process and approximately $70 \%$ in the static process, with $47 \mathrm{~h}$. At the beginning of agitated fermentation, total sugars and total soluble solids values were 121.6 and 130.0 $\mathrm{g} / \mathrm{L}$; after $29 \mathrm{~h}$, was detected 12.7 and $52.0 \mathrm{~g} / \mathrm{L}$, respectively. In static fermentation, total sugars and total soluble solids initial values were 120.7 and $135.0 \mathrm{~g} / \mathrm{L}$; with $47 \mathrm{~h}$, were observed 6.6 and $44.0 \mathrm{~g} / \mathrm{L}$, respectively. From 29 to $47 \mathrm{~h}$, total sugars consumption and total soluble solids declined more slowly. Fermentative studies ( $30{ }^{\circ} \mathrm{C}$ for 10 days) with banana (Musa sapientum) by Arruda et al. [18] and Akubor et al. [19] have also observed a decrease in total soluble solids content of 160.0 to $6.0 \mathrm{~g} / \mathrm{L}$ and 180.0 to $4.8 \mathrm{~g} / \mathrm{L}$, respectively. The incomplete alcoholic fermentation, with the presence of residual sugars, is a chronic problem in the fermented fruit industry; they result in a long fermentation process with microbial instability and unpleasant tastes in the final product [17]. A stuck fermentation occurs when the yeast does not fully consume the available sugars, reducing or stopping the fermentation rate.

\subsection{Kinetics parameters of alcoholic fermentation}

The experimental data on total sugars consumption and ethanol, glycerol and biomass production as a function of time, are shown in Fig. 2 and 3. 


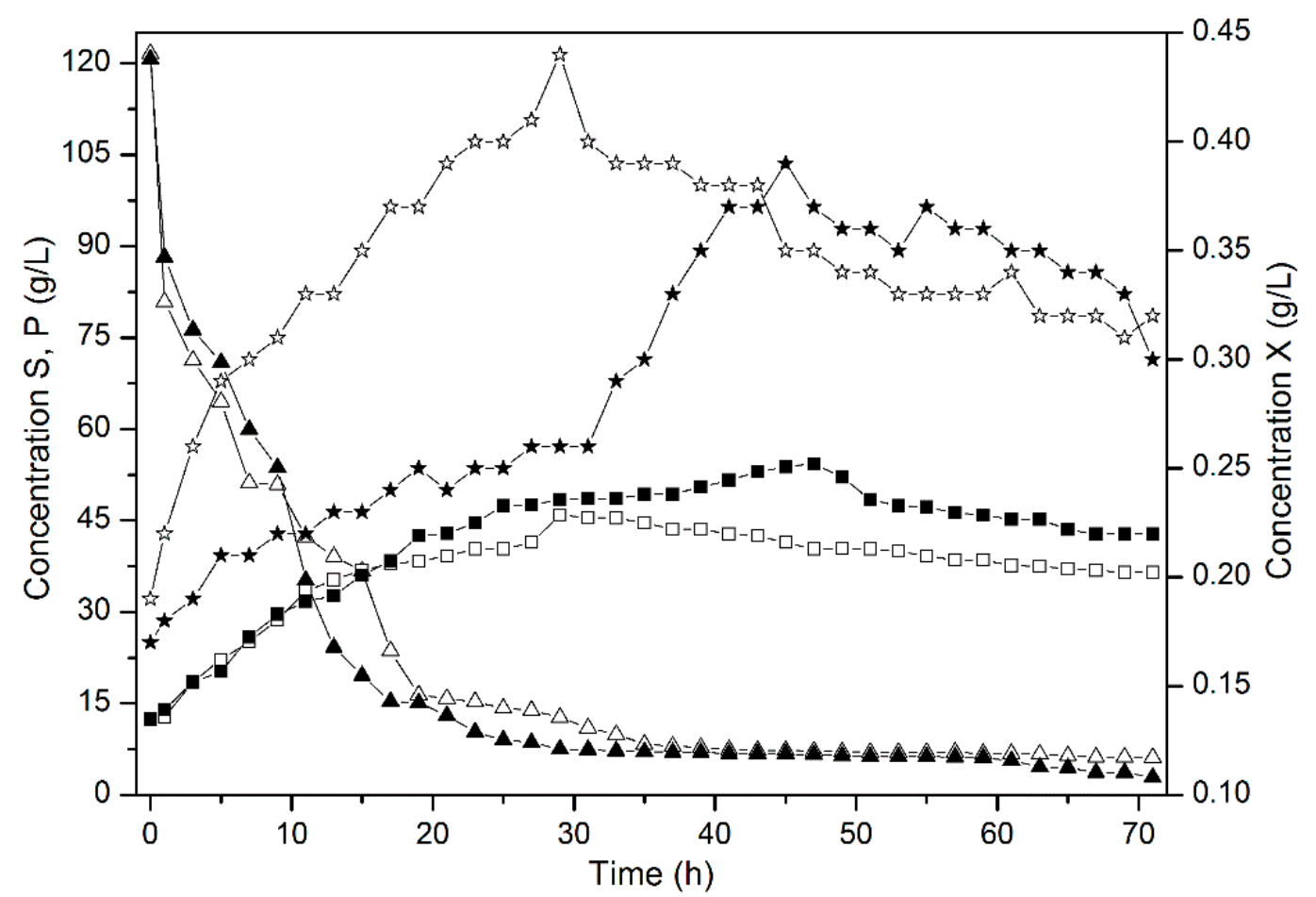

Fig. 2. Monitoring of alcoholic fermentation, agitated process as open forms and satic process as solid forms: $(\Delta)$ total sugars consumption $(S) ;(\square)$ ethanol production $(P)$; and $(飞)$ biomass production $(X)$ at $30{ }^{\circ} \mathrm{C}$ for $71 \mathrm{~h}$.

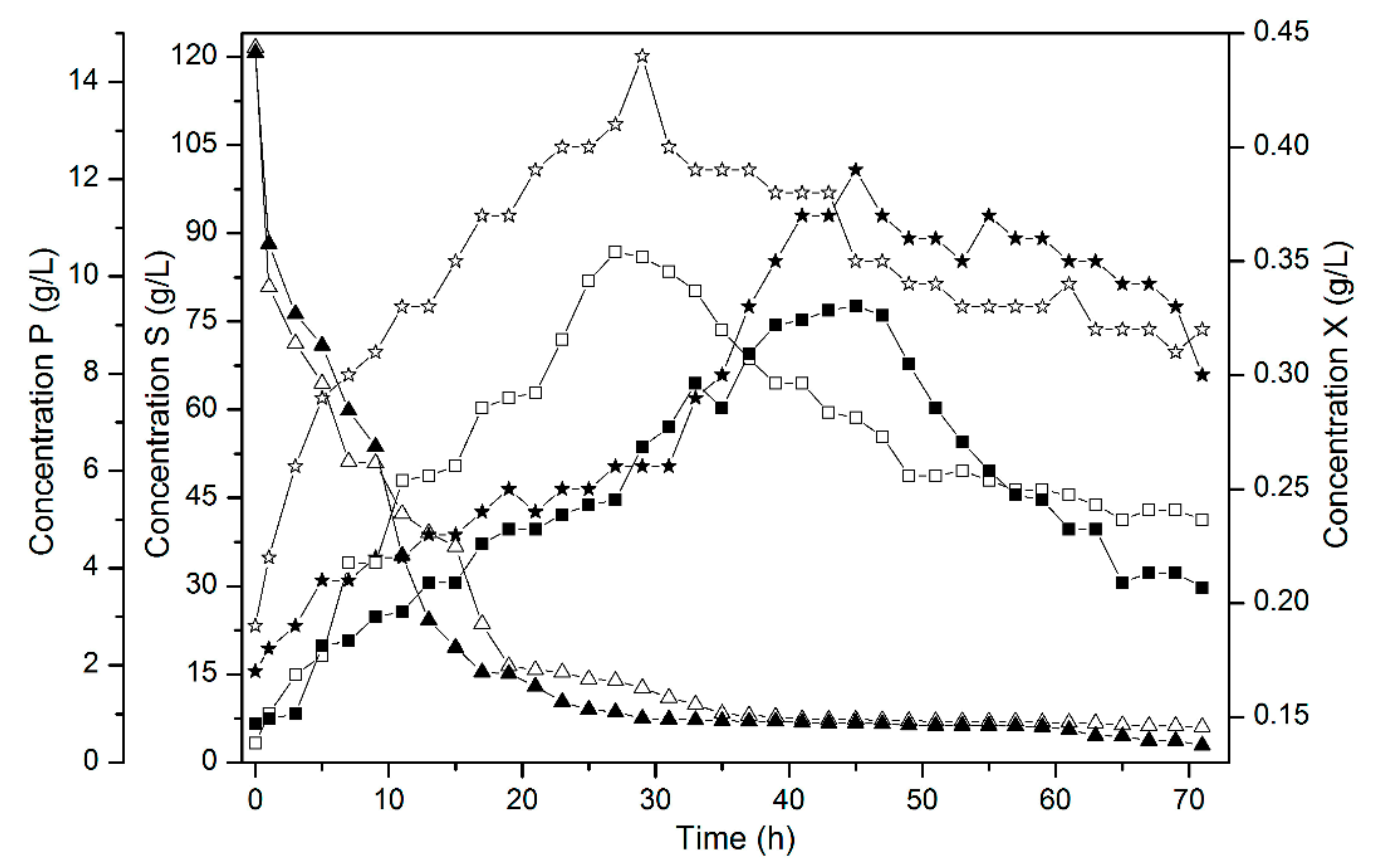

Fig. 3. Monitoring of alcoholic fermentation, agitated process as open forms and static process as solid forms: $(\Delta)$ total sugars consumption $(\mathrm{S})$; $(\square)$ glycerol production $(\mathrm{P})$; and ( $)$ biomass production $(\mathrm{X})$ at $30{ }^{\circ} \mathrm{C}$ for $71 \mathrm{~h}$.

Total sugars (S) consumption (converted into ethanol or glycerol $(\mathrm{P})$ ), the number of cells $(\mathrm{N})$, and the biomass $(X)$ as a function of fermentation time (h), shown in Fig. 2 and 3, obtained from experimental data, were used to predict the mathematical model generated from a third order polynomial fit, according to Equations (1-10), where RMSE is root-mean-square error. 


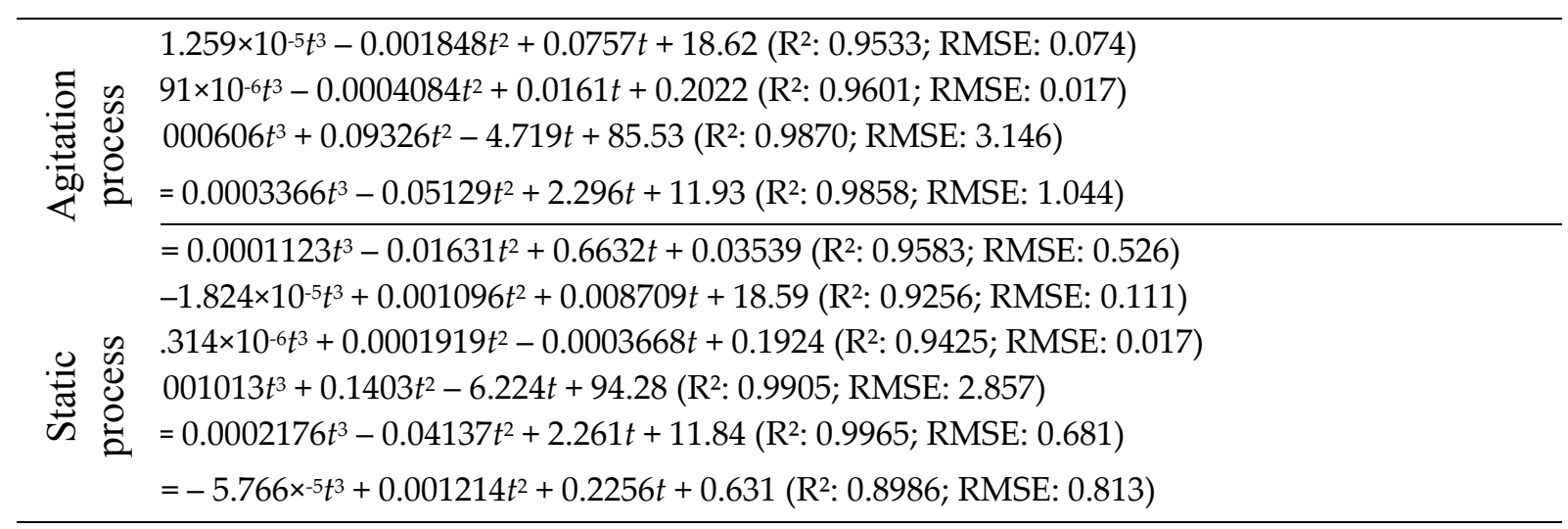

The kinetic parameters of the alcoholic fermentation processes were evaluated based on experimental data and on the values predicted by the mathematical model and are shown in Fig. 4 and 5.

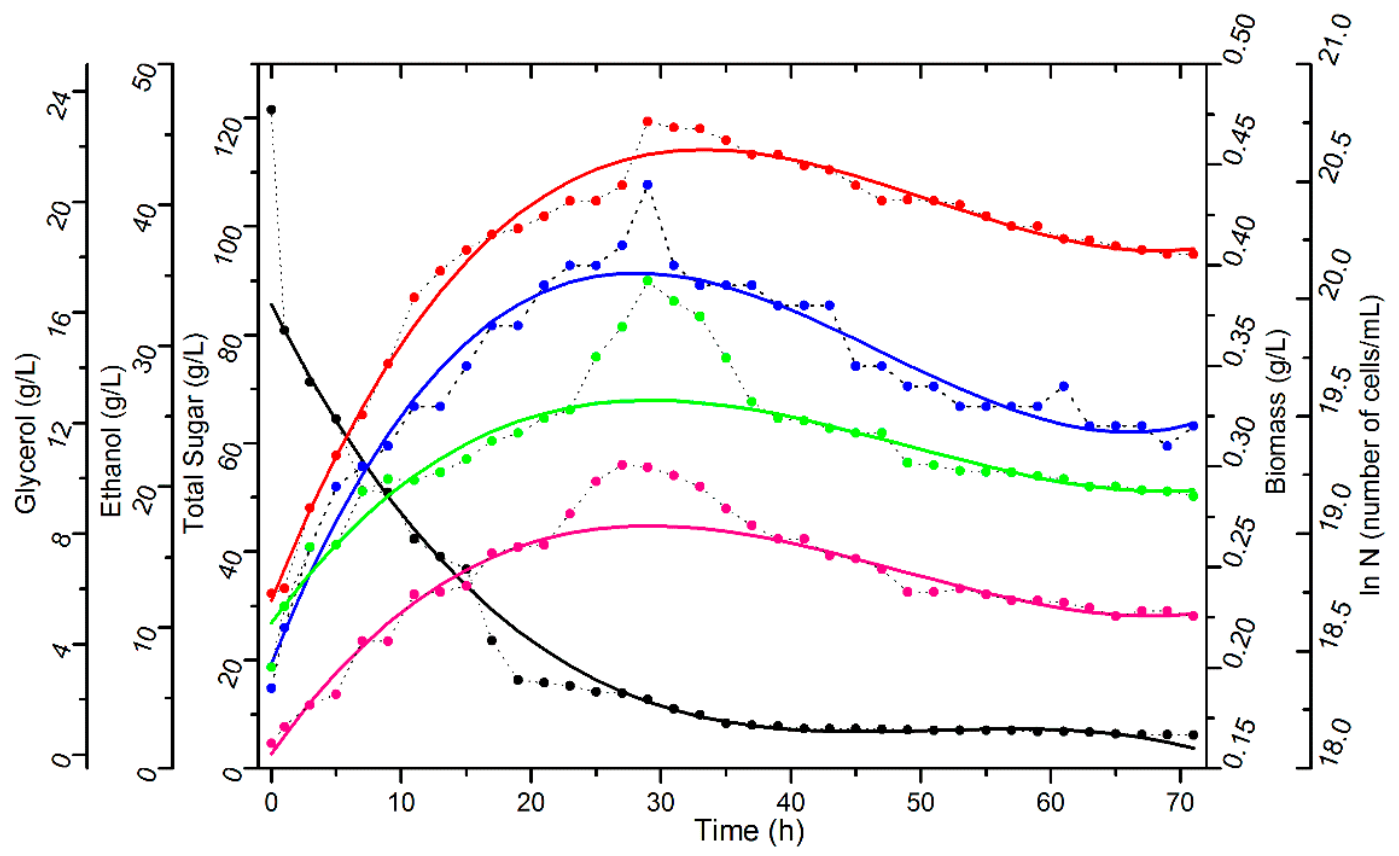

Fig. 4. Monitoring in agitated process: substrate consumption, products (ethanol and glycerol), number of cells and biomass formation for 71 hours of fermentation at $30^{\circ} \mathrm{C}$. Lines: black (total sugar - g/L); red (ethanol - g/L); pink (glycerol - g/L); blue (biomass - g/L) and green $(\mathbf{l n} \mathbf{N}$ - number of cells/mL), where ("o* experimental; - model). 


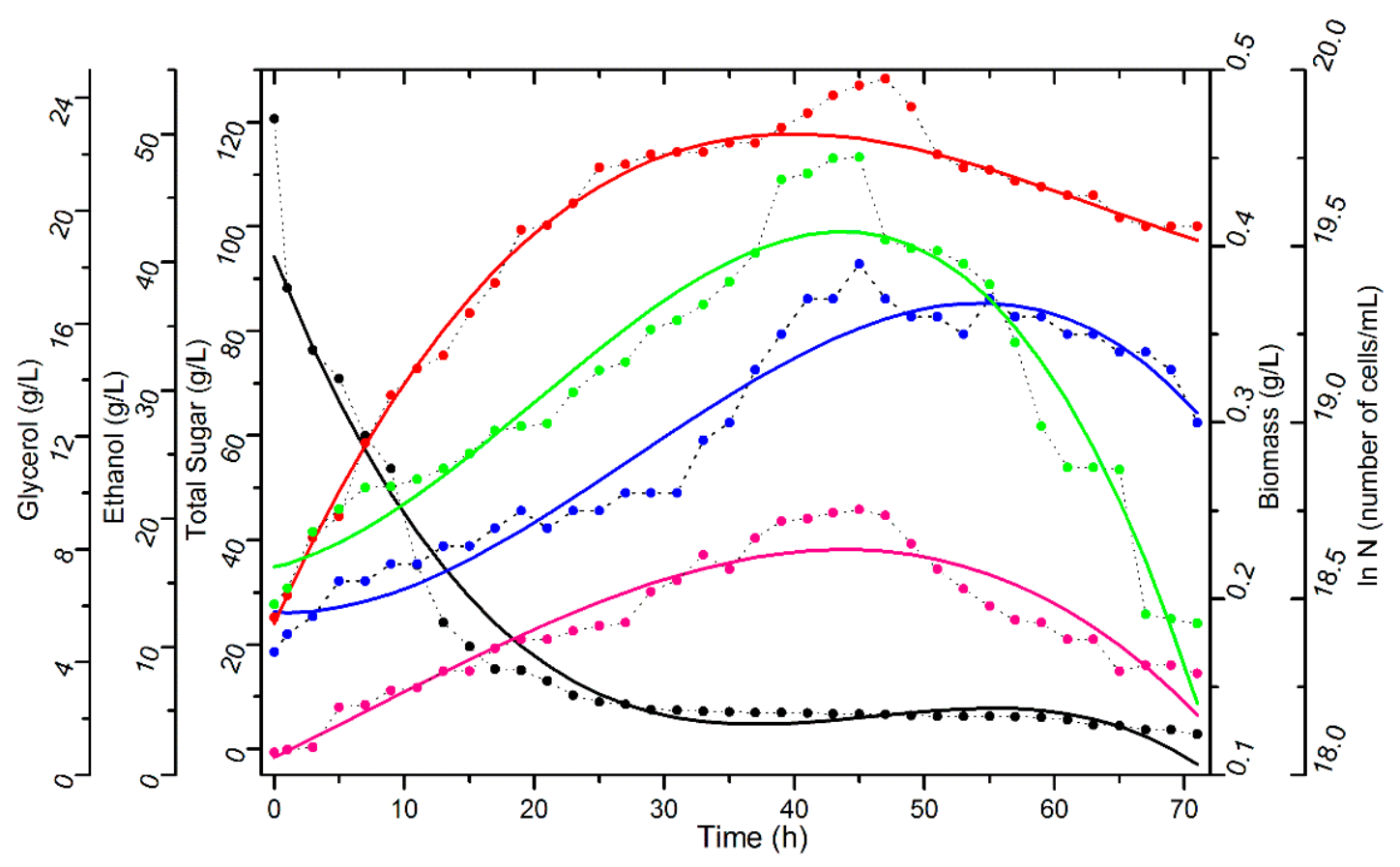

Fig. 5. Monitoring in static process: substrate consumption, products (ethanol and glycerol), number of cells and biomass formation for 71 hours of fermentation at $30{ }^{\circ} \mathrm{C}$. Lines: black (total sugar $-\mathrm{g} / \mathrm{L}$ ); red (ethanol - g/L); pink (glycerol - g/L); blue (biomass - g/L) and green $(\ln \mathbf{N}$ - number of cells/mL), where ("o" experimental; - model).

Table 3 shows the parameters determined after 27 and $29 \mathrm{~h}$ for the agitation process, and 45 and $47 \mathrm{~h}$ for the static process. These times represent the maximum amounts of glycerol and ethanol produced in each experiment, in accordance with Fig. 2 and 3.

In Table 3, Y1-ethanol values for the agitation and static processes were 53.91 and $68.10 \%$,

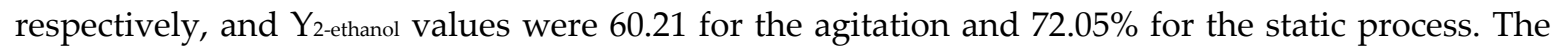
highest values were obtained in the static process. When analyzing yields in glycerol $\mathrm{Y}_{1 \text {-glycerol }}$ and $\mathrm{Y}_{2-}$ glycerol, the agitation process showed higher yields. Another parameter to be analyzed is productivity.

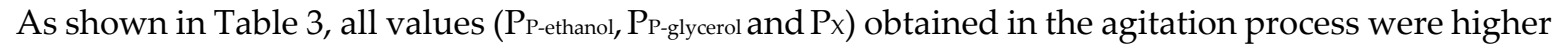
when compared to the static. 
Table 3. Kinetics parameters of alcoholic fermentation with agitation and static.

\begin{tabular}{|c|c|c|c|c|c|c|c|c|c|c|c|c|c|c|c|c|c|c|c|c|c|c|c|c|c|}
\hline \multirow{2}{*}{ Process } & \multicolumn{2}{|c|}{ Time $X$} & \multirow{2}{*}{$\frac{S}{g / L}$} & \multirow{2}{*}{$\frac{P_{\text {-et }}}{\mathrm{g} / \mathrm{L}}$} & \multirow{2}{*}{$\begin{array}{l}P_{-g l} \\
g / L\end{array}$} & \multirow{2}{*}{$\begin{array}{l}r_{x} \\
g / L h \\
\end{array}$} & \multirow{2}{*}{$\begin{array}{l}\mathrm{r}_{\mathrm{s}} \\
\mathrm{g} / \mathrm{Lh}\end{array}$} & \multirow{2}{*}{$\begin{array}{l}\mathrm{r}_{\text {p-et }} \\
\mathrm{g} / \mathrm{Lh}\end{array}$} & \multirow{2}{*}{$\begin{array}{l}\text { rp-gl } \\
g / L h\end{array}$} & \multirow{2}{*}{$\begin{array}{l}\mu_{\mathrm{x}} \\
\mathrm{h}^{-1}\end{array}$} & \multirow{2}{*}{$\frac{\mu_{\mathrm{s}}}{\mathrm{h}^{-1}}$} & \multirow{2}{*}{$\begin{array}{l}\mu_{\text {p-et }} \\
h^{-1}\end{array}$} & \multirow{2}{*}{$\begin{array}{l}\mu_{\mathrm{p}-\mathrm{gl}} \\
\mathrm{h}^{-1}\end{array}$} & \multirow{2}{*}{$\begin{array}{l}Y_{x / s} \\
\% \\
\end{array}$} & \multirow{2}{*}{$\begin{array}{l}Y_{x / p-e t} \\
\%\end{array}$} & \multirow{2}{*}{$\begin{array}{l}Y_{x / p-g 1} \\
\% \\
\end{array}$} & \multirow{2}{*}{$\begin{array}{l}Y_{\mathrm{p} / \mathrm{s}-\mathrm{et}} \\
\% \\
\end{array}$} & \multirow{2}{*}{$\begin{array}{l}Y_{\mathrm{p} / \mathrm{s}-\mathrm{gl}} \\
\%\end{array}$} & \multirow{2}{*}{$\begin{array}{l}\mathrm{P}_{\mathrm{x}} \\
\mathrm{g} / \mathrm{Lh}\end{array}$} & \multirow{2}{*}{$\begin{array}{l}P_{p-e t} \\
g / L h\end{array}$} & \multirow{2}{*}{$\frac{P_{p-g l}}{g / L h}$} & \multirow{2}{*}{$\begin{array}{l}Y_{1-\text { et }} \\
\%\end{array}$} & \multirow{2}{*}{$\begin{array}{l}Y_{1-\mathrm{gl}} \\
\% \\
\end{array}$} & \multirow{2}{*}{$\begin{array}{l}Y_{2-\text { et }} \\
\%\end{array}$} & \multirow{2}{*}{$\begin{array}{l}Y_{2-g l} \\
\%\end{array}$} \\
\hline & $\mathrm{h}^{\mathrm{a}}$ & $\mathrm{g} / \mathrm{L}$ & & & & & & & & & & & & & & & & & & & & & & & \\
\hline \multirow{2}{*}{ Agitated } & 0 & 0.19 & 121.6 & 12.4 & 04 & - & - & - & & - & 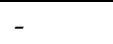 & & & 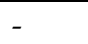 & - & 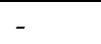 & 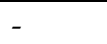 & - & & 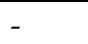 & & - & - & 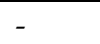 & - \\
\hline & 27 & 90.44 & 12.7 & 45.9 & 10.5 & 007 & & & 0.357 & & & & & & & & & & & & & & & & \\
\hline \multirow{2}{*}{ Static } & 0 & 0.17 & 20.7 & & 0 & - & - & - & & - & 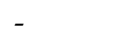 & - & & . & - & - & & & - & - & & - & & - & \\
\hline & $45 / 47$ & 70.37 & 6.6 & 54.3 & 9.4 & 0.007 & 7.659 & 1.450 & 0.181 & 0.020 & 20.408 & 6.164 & 3.063 & 0.175 & 0.476 & 2.558 & 36.819 & 7.547 & 0.005 & 0.893 & 0.191 & 68.10 & 1.54 & 72.05 & 1.82 \\
\hline
\end{tabular}

a 27 and $45 \mathrm{~h}$ maximum glycerol production; 29 and $47 \mathrm{~h}$ maximum ethanol production. Abreviation et: ethanol; gl: glycerol 
It is expected that the process with the highest value for the conversion factor to ethanol (YP/sethanol) would have the lowest value for the glycerol conversion factor $\left(\mathrm{Y}_{\mathrm{P} / \mathrm{s}-\mathrm{gly} \text { cerol }}\right)$. This was confirmed in the static process, while the opposite occurred in the agitation process. This parameter confirms that the glycerol formed may have lead to a decreased ethanol concentration in the wine. Moreover, when comparing the conversion factors of substrate into products ( $\mathrm{Y}_{\mathrm{P} / \mathrm{s} \text {-ethanol }}$ and $\mathrm{Y} / \mathrm{p} / \mathrm{s}$-glycerol), for both process, with the conversion factor of substrate for the formation of biomass ( $Y \times / s)$, we confirmed what had been previously reported, i.e., that the microorganism prefers the fermentation pathway regardless of the presence or absence of oxygen.

\subsection{Characterization of wines}

The wines characterization are shown in Table 1 . Values of fixed acidity were 2.8 and $3.2 \mathrm{~g} / \mathrm{L}$; titratable acidity were 3.9 and $4.4 \mathrm{~g} / \mathrm{L}$ and volatile acidity were 1.1 and $1.2 \mathrm{~g}$ of acetic acid/L, for the agitation and static processes, respectively. Alvarenga et al. [2] found titratable acidity values between 4.6 and $6.1 \mathrm{~g}$ of acetic acid/L for banana wines (M. sapientum), which are higher than those obtained in our result. High volatile acidity levels indicate bacterial activity, such as lactic or acetic bacteria, damaging the sensory quality of wine.

Total sugars found in wine obtained in the agitation and static processes were 12.68 and 7.29 $\mathrm{g} / \mathrm{L}$, respectively. Stuck fermentation was observed in all studies. Alcohol content at $20{ }^{\circ} \mathrm{C}$ in the agitated fermentation was $5.73 \%(\mathrm{v} / \mathrm{v})$ and $6.81 \%$ in the static. These differences may be explained by the amount of sugar present in the substrate and by the different conditions of fermentation.

The final products $\mathrm{pH}$ values were 4.0 for both fermentation processes. Ash content was 11.25 $\mathrm{g} / \mathrm{L}$ in the agitation process and $8.63 \mathrm{~g} / \mathrm{L}$ in the static. Ash content is a parameter used to detect fraud in fermented alcoholic beverages.

For total dry extract - the total of non-volatile substances remaining after evaporation or distillation process, such as carbohydrates, glycerine, non-volatile acids, nitrogenous compounds, tannic substances, higher alcohols and minerals - we obtained 38.17 for the agitation and $28.20 \mathrm{~g} / \mathrm{L}$ for static process.

Table 4 presents the secondary compounds found in wines. Ten components were found, such as acid (1), alcohols (6), ester (1), aldehyde (1) and furan (1); $n$-butyl alcohol was not present in the static process. Wine aroma can be influenced by many factors, including raw material, fermentation conditions, microorganisms strains, the wine-making process, aging and storage conditions [20].

Table 4. Volatile compounds of banana alcoholic and acetic fermented beverages.

\begin{tabular}{|c|c|c|c|c|c|c|c|}
\hline \multicolumn{2}{|c|}{ Compounds (mg/L)a } & \multicolumn{2}{|c|}{ Wine - Agitation } & \multicolumn{2}{|c|}{ Wine - Static } & \multicolumn{2}{|c|}{ Vinegar } \\
\hline Acid & Acetic acid ${ }^{b}$ & - & $205.5( \pm 4.91)$ & - & $448.4( \pm 9.52)$ & - & $\begin{array}{l}49,200.0 \\
( \pm 456.9)\end{array}$ \\
\hline \multirow[t]{7}{*}{ Alcohols } & $\begin{array}{l}\text { Methyl } \\
\text { alcohol }\end{array}$ & $3.030^{c}$ & $269.4( \pm 5.23)$ & $3.031^{\mathrm{c}}$ & $282.0( \pm 4.75)$ & $3.020^{c}$ & $97.3( \pm 8.17)$ \\
\hline & $\begin{array}{l}\text { Iso-amyl } \\
\text { alcohol }\end{array}$ & $7.864^{c}$ & $175.6( \pm 4.18)$ & $7.861^{\mathrm{c}}$ & $213.0( \pm 6.69)$ & $7.867^{c}$ & $7.1( \pm 2.53)$ \\
\hline & $\begin{array}{l}\text { Iso-butyl } \\
\text { alcohol }\end{array}$ & $6.439^{c}$ & $73.1( \pm 3.42)$ & $6.442^{c}$ & $84.8( \pm 4.13)$ & $6.437 c$ & $1.3( \pm 0.12)$ \\
\hline & $\begin{array}{l}N \text {-butyl } \\
\text { alcohol }\end{array}$ & $6.872^{c}$ & $0.9( \pm 0.17)$ & - & nd & - & nd \\
\hline & $\begin{array}{l}\text { Propyl } \\
\text { alcohol }\end{array}$ & $5.518^{c}$ & $46.2( \pm 1.99)$ & $5.517^{c}$ & $55.1( \pm 2.34)$ & - & nd \\
\hline & $\begin{array}{l}\text { Sec-butyl } \\
\text { alcohol }\end{array}$ & - & nd & - & nd & - & nd \\
\hline & Glycerol & - & $\begin{array}{l}10,400.0 \\
( \pm 102.3)\end{array}$ & - & $\begin{array}{l}9,200.0 \\
( \pm 98.71)\end{array}$ & - & nd \\
\hline Aldehydes & Acetaldehyde & $1.724^{c}$ & $22.1( \pm 2.18)$ & $1.724^{c}$ & $89.9( \pm 3.22)$ & $1.724^{c}$ & $8.1( \pm 0.21)$ \\
\hline
\end{tabular}




$\begin{array}{llllllll}\text { Ester } & \text { Ethyl acetate } & 2.874^{c} & 18.1( \pm 1.34) & 2.874^{c} & 23.2( \pm 2.25) & 2.872^{c} & 44.2( \pm 5.17) \\ \text { Furans } & \text { Furfural } & 11.134 & 2.6( \pm 0.28) & 11.133 & 3.5( \pm 0.37) & 11.131 & 15.4( \pm 1.27)\end{array}$

a triplicate values. ${ }^{b}$ determined by volumetric neutralization of the sample after distillation by drag steam. ${ }^{c}$ Retention Time (min.). nd: not identified

The final products showed ethyl acetate content of 18.1 for the agitation and $23.2 \mathrm{mg} / \mathrm{L}$ for the static processes. The presence of esters compounds in wines contributes positively to sensory characteristics, such as sweetness and fruity aromas in the beverage [21].

Acetic acid gives the wine its spicy aroma, being the main volatile acid in fermented drinks, recognized by its negative effects on the analytical wine profile [2]. We found 205.5 of acetid acid for the agitation process and $448.4 \mathrm{mg} / \mathrm{L}$ for the static, respectively.

The acetaldehyde concentration in the fermentation process with agitation was 22.1 and 89.9 $\mathrm{mg} / \mathrm{L}$ in the static. According to Bortoletto and Alcarde [14], aldehydes are considered intermediate compounds in the formation of higher alcohols, conferring wines their pleasant aroma and taste.

Furfural results were 2.6 in the agitation and $3.5 \mathrm{mg} / \mathrm{L}$ in the static process. This compound is produced by the Maillard reaction [22]. According to Taherzadeh et al. [23], furfural reduces the growth rate and the ethanol production, being also a glucose inhibitor in the S. cerevisiae fermentation.

Alcohols are flavoring, but in high concentrations, they are toxic and harmful to health (especially the iso-amyl alcohols and methanol), impairing the final product quality [3]. Methanol concentration was 269.4 and $282.0 \mathrm{mg} / \mathrm{L}$ and iso-amyl alcohol was 175.6 and $213.0 \mathrm{mg} / \mathrm{L}$ for the agitation and static processes, respectively. According to Spinosa et al. [4], methanol should not exceed $350.0 \mathrm{mg} / \mathrm{L}$ in wines. The production of methanol and higher alcohols can be reduced by the addition of pectinolytic enzymes to the must, thus increasing ethanol yields, improving the aroma and color compounds, making the beverage clarification and filtration easier [24, 25].

Products with low concentrations of higher alcohols are considered to be of good quality [21]. Total concentration of higher alcohols (iso-amyl, iso-butyl, $n$-butyl, propyl and sec-butyl alcohol) in the agitation and static processes were 295.8 and $352.9 \mathrm{mg} / \mathrm{L}$, respectively. Glycerol concentration in wines were 10.4 (agitated) and $9.2 \mathrm{~g} / \mathrm{L}$ (static), the most abundant component of higher alcohols. Lower levels of higher alcohols, except for glycerol and $n$-butyl alcohol, were found in the agitation process. Glycerol content is related to wine quality; in amounts ranging between 7.0-8.0 g/L, it gives sweetness and smooth flavour to wines [3].

The mineral compounds found in the wines were consistent to those found in the banana pulp (Table 2). Calcium, magnesium, potassium and phosphorus concentrations decreased after the alcoholic fermentation in both processes. This may be due to cell maintenance and yeast proliferation. Sulfur, iron, manganese, aluminum, silicon and zinc concentrations in the wines incresead when compared to the banana pulp, especially the sulfur. Sulfur compounds are present in wines at low concentrations and may derive from yeast metabolism, in species $S$. cerevisiae [26]. $\mathrm{H}_{2} \mathrm{~S}$ is an intermediate metabolite of the sulfate reduction pathway, which is a part of the sulfur amino acid biosynthesis. Other factors may also explain the presence of sulfur in wines, such as pesticides degradation, release and/or metabolism of sulfur precursors present in the fruit, or even supplementary agents added to the must [26].

Boron, nickel, copper, molybdenum and sodium remained virtually constant for both the pulp and the wines. For potassium, the pulp $(3.05 \mathrm{~g} / \mathrm{L})$ showed a higher concentration of the mineral compared to wines for the agitation $(1.61 \mathrm{~g} / \mathrm{L})$ and static processes $(2.25 \mathrm{~g} / \mathrm{L})$. Potassium, calcium $(34.60 \mathrm{mg} / \mathrm{L}$ (agitation) and $37.23 \mathrm{mg} / \mathrm{L}$ (static)) and iron $(3.05 \mathrm{mg} / \mathrm{L}$ (agitation) and $3.03 \mathrm{mg} / \mathrm{L}$ (static)) concentrations obtained in this study were similar to those found by Arruda et al. [18] of $2.63 \mathrm{~g} / \mathrm{L}$, $35.18 \mathrm{mg} / \mathrm{L}$ and $1.40 \mathrm{mg} / \mathrm{L}$, respectively, in banana wine.

\subsection{Kinetics parameters of acetic fermentation}

The results related to the monitoring of acetic fermentation in cycles are listed in Table 5. All means were calculated disregarding the first cycle, as these are considered an adaptation [4]. 
Table 5. Acetic fermentation monitoring.

\begin{tabular}{|c|c|c|c|c|c|c|c|c|c|c|c|c|c|c|c|}
\hline \multirow{3}{*}{ Cycle } & \multicolumn{4}{|l|}{ Acetator } & \multicolumn{5}{|c|}{ Product } & \multicolumn{3}{|l|}{ Yields } & \multicolumn{3}{|l|}{ Cells } \\
\hline & $\mathrm{t}$ & $\mathrm{T}$ & $\mathrm{V}_{1}$ & $\mathrm{TC}_{1}$ & $\mathrm{~V}_{2}$ & $\mathrm{pH}$ & $\mathrm{A}$ & $\mathrm{E}$ & $\mathrm{TC}_{2}$ & $\eta_{\mathrm{AA}}$ & $\mathrm{P}_{\mathrm{AA}}$ & $R_{G K}$ & $\mathrm{~N}$ & $\mathrm{LC}$ & $\mathrm{DC}$ \\
\hline & $\mathrm{h}$ & ${ }^{\circ} \mathrm{C}$ & $\mathrm{L}$ & $\%$ & $\mathrm{~L}$ & & $\mathrm{~g} / \mathrm{L}$ & $\mathrm{g} / \mathrm{L}$ & $\%$ & $\%$ & $\mathrm{~g} / \mathrm{Lh}$ & $\%$ & $\log / m L$ & $\%$ & $\%$ \\
\hline \multirow{2}{*}{1} & - & 30.3 & 3.9 & 8.0 & - & - & - & - & - & - & - & - & - & - & - \\
\hline & 144.5 & - & - & - & 1.0 & 2.7 & 68.0 & 3 & 7.1 & 72.7 & 0.078 & 88.8 & 8.6 & 98.9 & 1.1 \\
\hline \multirow{2}{*}{2} & - & 30.1 & 4.0 & 6.1 & - & - & - & - & - & - & - & - & - & - & - \\
\hline & 22.2 & - & - & - & 0.3 & 2.8 & 55.0 & 5 & 6.0 & 58.8 & 0.124 & 99.2 & 8.5 & 99.0 & 1.0 \\
\hline \multirow{2}{*}{3} & - & 30.3 & 4.1 & 6.2 & - & - & - & - & - & - & - & - & - & - & - \\
\hline & 21.3 & - & - & - & 1.0 & 2.8 & 56.0 & 5 & 6.1 & 59.9 & 0.438 & 98.9 & 8.5 & 99.3 & 0.7 \\
\hline \multirow{2}{*}{4} & - & 30.2 & 4.2 & 6.5 & - & - & - & - & - & - & - & - & - & - & - \\
\hline & 48.3 & - & - & - & 1.0 & 2.9 & 59.0 & 3 & 6.2 & 63.1 & 0.204 & 95.9 & 8.3 & 97.5 & 2.5 \\
\hline \multirow{2}{*}{5} & - & 30.3 & 4.3 & 5.1 & - & - & - & - & - & - & - & - & - & - & - \\
\hline & 26.0 & - & - & - & 1.0 & 2.8 & 47.0 & 2 & 4.9 & 50.3 & 0.301 & 97.6 & 8.4 & 98.8 & 1.4 \\
\hline \multirow{2}{*}{6} & - & 30.2 & 4.7 & 4.6 & - & - & - & - & - & - & - & - & - & - & - \\
\hline & 50.8 & - & - & - & 1.0 & 2.9 & 40.0 & 5 & 4.5 & 42.8 & 0.131 & 98.4 & 8.3 & 97.8 & 2.2 \\
\hline \multirow{2}{*}{7} & - & 30.2 & 4.6 & 4.5 & - & - & - & - & - & - & - & - & - & - & - \\
\hline & 71.1 & - & - & - & 1.0 & 2.9 & 41.0 & 7 & 4.8 & 43.8 & 0.096 & 90.8 & 8.1 & 95.3 & 4.7 \\
\hline Average $^{a}$ & $39.9 \pm 20.1$ & & & & & & $49.7 \pm 8.1$ & & $5.4 \pm 0.8$ & $53.1 \pm 8.7$ & $0.216 \pm 0.13$ & $96.8 \pm 3.2$ & $8.3 \pm 0.2$ & $97.9 \pm 1.5$ & $2.1 \pm 1.5$ \\
\hline
\end{tabular}

a Average from cycle 2 to 7 . $\mathbf{t}$ : Fermentation time. T: Temperature. V1: Volume of liquid in the acetator. TC1: Total concentration of acetator. V: Volume of produced vinegar.

A: Vinegar acidity. E: Ethanol in wine. TC2: Total concentration in vinegar. LC: Living Cells. DC: Dead Cell. 
The average time for the acetification of banana wine (Table 5 and Fig. 6) was $39.9 \mathrm{~h}$. The lowest time was $21.3 \mathrm{~h}$ (third cycle) and the highest was 71.1 (seventh cycle). A previous study by Spinosa et al. [4] for submerged fermentation, fed-batch, at $30^{\circ} \mathrm{C}$ in a bioreactor Frings ${ }^{\circledast}$, followed by 10 cycles, found an average time of $28.8 \mathrm{~h}$ for acetic acid fermentation of rice wine, ranging from 21.0 to $40.5 \mathrm{~h}$. The peak of acetic acid in the banana vinegar $(59.0 \mathrm{~g} / \mathrm{L})$ was reached at $48.3 \mathrm{~h}$. In a cashew and kiwifruit vinegar study, Silva et al. [27] and Bortolini et al. [28], found the maximum concentration of acetic acid at 50.0 and $12.0 \mathrm{~h}$, respectively, in a submerged process. The concentration of acetic acid in banana vinegar ranged from 59.0 to $40.0 \mathrm{~g} / \mathrm{L}$, with an average of $49.7 \mathrm{~g} / \mathrm{L}$. This indicates a low rate of conversion of alcohol into acid, since the wine showed an alcohol content of $72.0 \mathrm{~g} / \mathrm{L}$. Spinosa et al. [4] found a mean concentration of $71.1 \mathrm{~g} / \mathrm{L}$ of acetic acid, for rice vinegar.

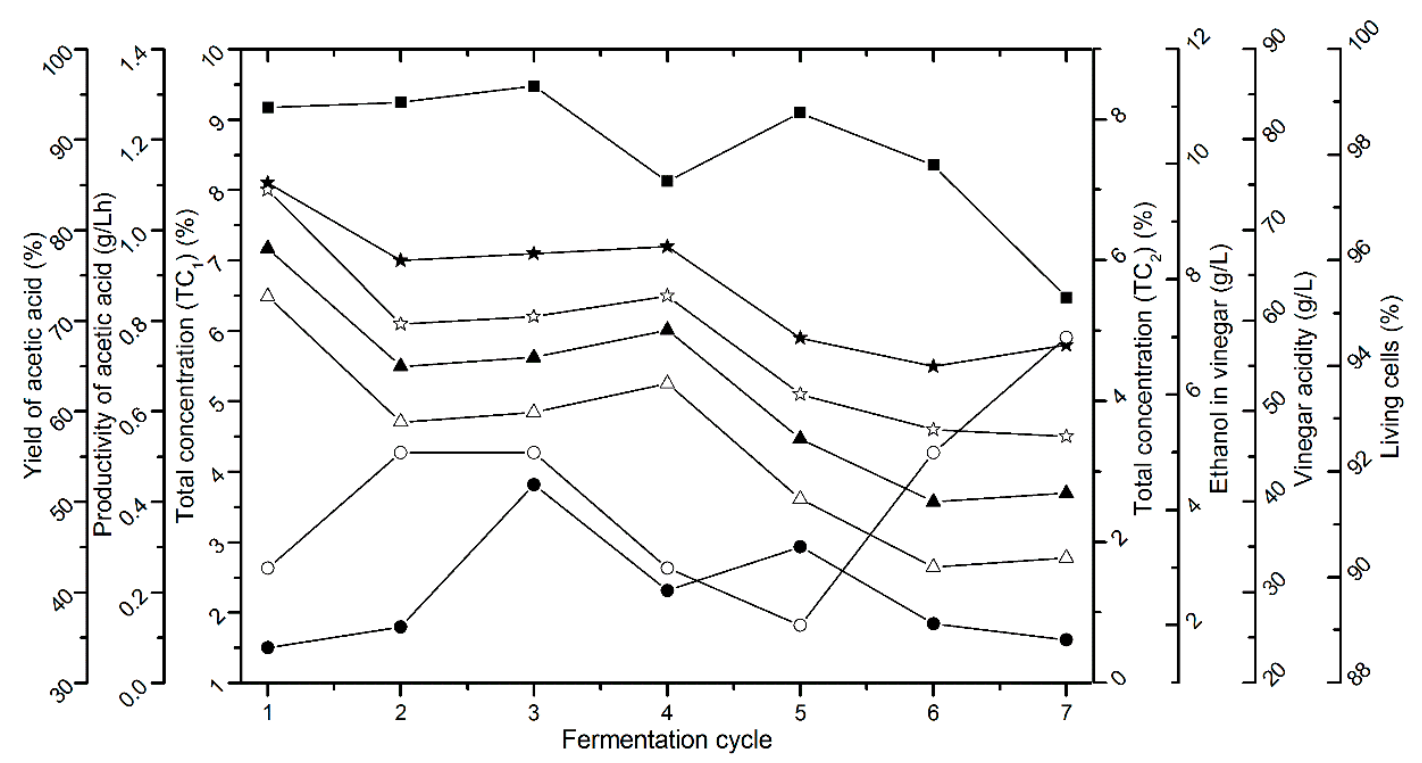

Fig. 6. Monitoring acetic fermentation from banana wine: (하) total concentration of acetator $-\mathrm{TC}_{1}$, $(\star)$ total concentration in vinegar $-\mathrm{TC}_{2},(\Delta)$ acetic acid yield, $(\boldsymbol{\Delta})$ vinegar acidity, $(\bullet)$ acetic acid productivity, ( $\circ$ ) ethanol in vinegar; and (₫) living cells, from 7 cycles.

The wine $\mathrm{pH}$ was 4.0 (Table 1); it decresead to 2.85 after the acetic fermentation, ranging betwen 2.8 and 2.9. Spinosa et al. [4] and Bortolini et al. [28] found $\mathrm{pH}$ values of 2.7 and 3.6 for rice and kiwifruit vinegars, respectively.

The acetic acid yield values showed a decrease over the cycles, ranging from 42.8 to $63.1 \%$, with average of 53.1\%. Bortolini et al. [28] obtained higher yields in kiwifruit vinegar, ranging from 93.2 to $98.3 \%$ and Spinosa et al. [4] found a mean value of $88.2 \%$ for rice vinegar. Acetic acid productivity values ranged from 0.096 to $0.438 \mathrm{~g} / \mathrm{Lh}$, with mean of $0.216 \mathrm{~g} / \mathrm{Lh}$. Bortolini et al. [28] reported a variation from 0.830 to $1.730 \mathrm{~g} / \mathrm{Lh}$ in the submerged process. Silva et al. [27] and Spinosa et al. [4] obtained mean yield values ranging of 0.550 and $0.730 \mathrm{~g} / \mathrm{Lh}$ for cashew and rice vinegar, respectively. GK yield values ranged from 90.8 to $99.2 \%$, with a mean of $96.8 \%$.

The conversion rate of acetic acid depends on many factors such as temperature, oxygen availability, inoculum quantity, initial concentration of alcohol and acetic acid. The bioreactor dimensions also impact directly in the fermentation time and in the bioconversion rates. According to Spinosa et al. [4], the efficiency of the submerged process is directly related to the reactor aeration system.

\subsection{Characterization of vinegar}

Values of fixed acidity, titratable acidity and volatile acidity of $17.9,44.1$ and $26.2 \mathrm{~g} / \mathrm{L}$, are expressed in acetic acid (Table 1), respectively. Marques et al. [29] reported volatile acidity values for orange, tangerine, mango, kiwi fruit and apple vinegar of 27.4 to $41.7 \mathrm{~g} / \mathrm{L}$. Bortolini et al. [28] found 
acidity values ranging from 50.1 to $51.3 \mathrm{~g} / \mathrm{L}$, for kiwi fruit vinegar. The vinegar acidity has great influence on the sensorial acceptance of the product [29].

In North America and Brazil, an acetic acid content of at least $4 \%(\mathrm{w} / \mathrm{v})$ is required for the product to be sold as vinegar [30]. The vinegar produced in the present study, showed $49.2 \mathrm{~g} / \mathrm{L}$ of acetic acid with a the total sugars value of $10.27 \mathrm{~g} / \mathrm{L}$ and ashes $3.73 \mathrm{~g} / \mathrm{L}$. The vinagers produced by Marques et al. [29] with orange, tangerine, mango, kiwifruit and apple showed values between 1.49 $-3.65 \mathrm{~g} / \mathrm{L}$ of ashes.

Brazilian law allows fruit vinegars to have a minimum of $1.0 \mathrm{~g} / \mathrm{L}$ and a maximum of $5.0 \mathrm{~g} / \mathrm{L}$ of ashes [31]. The total and reduced dry extract content of banana vinegar were 21.23 and $10.96 \mathrm{~g} / \mathrm{L}$, respectively; the minimum required by Brazilian law for reduced dry extract is $6.0 \mathrm{~g} / \mathrm{L}$ [31]. Marques et al. [29] found total dry extract values between $8.9-38.3 \mathrm{~g} / \mathrm{L}$ for differents fruit vinegars.

There was no alcohol content at $20^{\circ} \mathrm{C}(\mathrm{v} / \mathrm{v})$ in the banana vinegar, as well as all the other vinegars analyzed by Marques et al. [29]. However, Bortolini et al. [28] found alcohol content of 0.32 to $0.49 \%$ $(\mathrm{v} / \mathrm{v})$ for kiwifruit vinegar. Brazilian law allows, at most, $1.0 \%$ of alcohol (v/v) at $20{ }^{\circ} \mathrm{C}$ in fruit vinegars. According to Marques et al. [29], the presence of small quantities of residual alcohol reflects favorably on the vinegars flavour, by bouquet formation. The banana vinegar $\mathrm{pH}$ was 3.21, a value close to those reported by Marques et al. [29] between 3.51 and 2.65 for fruit vinegars.

It is worth noticing that the vinegar obtained was similar to those reported in the literature and in compliance with the Brazilian law. However, the banana vinegar showed lower yields and productivity. This may be related to the raw material used and to the acetification system employed, which also influences the vinegar final quality. That is why the volatile compounds of the final product were analyzed, since they contribute to the characteristic flavour and aroma of the substrate used in both alcoholic and acetic fermentation [4, 21].

The volatile compounds of wine and vinegars are mainly alcohols and esters. The iso-amyl alcohol is consumed during the acetification process and the esters concentration increases during the vinegar maturation and aging. Initial alcohol content in vinegars is an important factor to develop certain flavouring compounds, mainly from ethyl acetate [32]. When comparing the amoung compounds found in wine and vinegar (Table 5), the iso-amyl alcohol concentrations in wine were of $213.0 \mathrm{mg} / \mathrm{L}$; after the acetic fermentation, it decreased to $7.1 \mathrm{mg} / \mathrm{L}$. The ethyl acetate (ester) concentration increased from $23.2 \mathrm{mg} / \mathrm{L}$ in wine to $44.2 \mathrm{mg} / \mathrm{L}$ in vinegar, similar to those described by Morales et al. [32].

The acetaldehyde concentration also decreased, from $89.9 \mathrm{mg} / \mathrm{L}$ in wine obtained in the static process to $8.1 \mathrm{mg} / \mathrm{L}$. According to Reddy et al. [33], acetaldehyde is a primary metabolite formed converting ethanol into acetic acid by acetic bacteria. After acetification, the acetic acid concentration increased from $448.4 \mathrm{mg} / \mathrm{L}$ in wine to $49.2 \mathrm{~g} / \mathrm{L}$ in vinegar.

Furfural values increased from $3.5 \mathrm{mg} / \mathrm{L}$ in wine (static process) to $15.4 \mathrm{mg} / \mathrm{L}$ in vinegar, which is a favorable aspect, since furans are compounds that give the sweet and fruity flavour to the beverage [3].

There was a decrease in all mineral compounds after acetification (except for phosphorus, manganese and nickel which increased) comparing vinegar (Table 2) to the wine (static process) and the pulp. Sulfur concentration in vinegar increased when compared to the pulp, and decresead when compared to wine, while the molybdenum has remained fairly constant in both processes (alcoholic and acetic fermentation). As previously discussed, minerals are important for they keep the microorganisms integrity (yeasts and acetic bacteria).

\section{Conclusions}

This study revealed that the production of wine and vinegar from banana pulp is feasible, presenting chemical and mineral compounds in their composition with sensory and nutritional interest. The ethanol yield in the static process was higher, and the glycerol was lower compared to the agitated process. The productivity in the agitation process was higher than in the static, and the time in this process was shorter to obtain the maximum production. Wine obtained in the static 
process had higher levels of volatile compounds. The vinegar reached adequate acidity values and the concentration of ethyl acetate was higher than in the wines.

\section{Nomenclature}

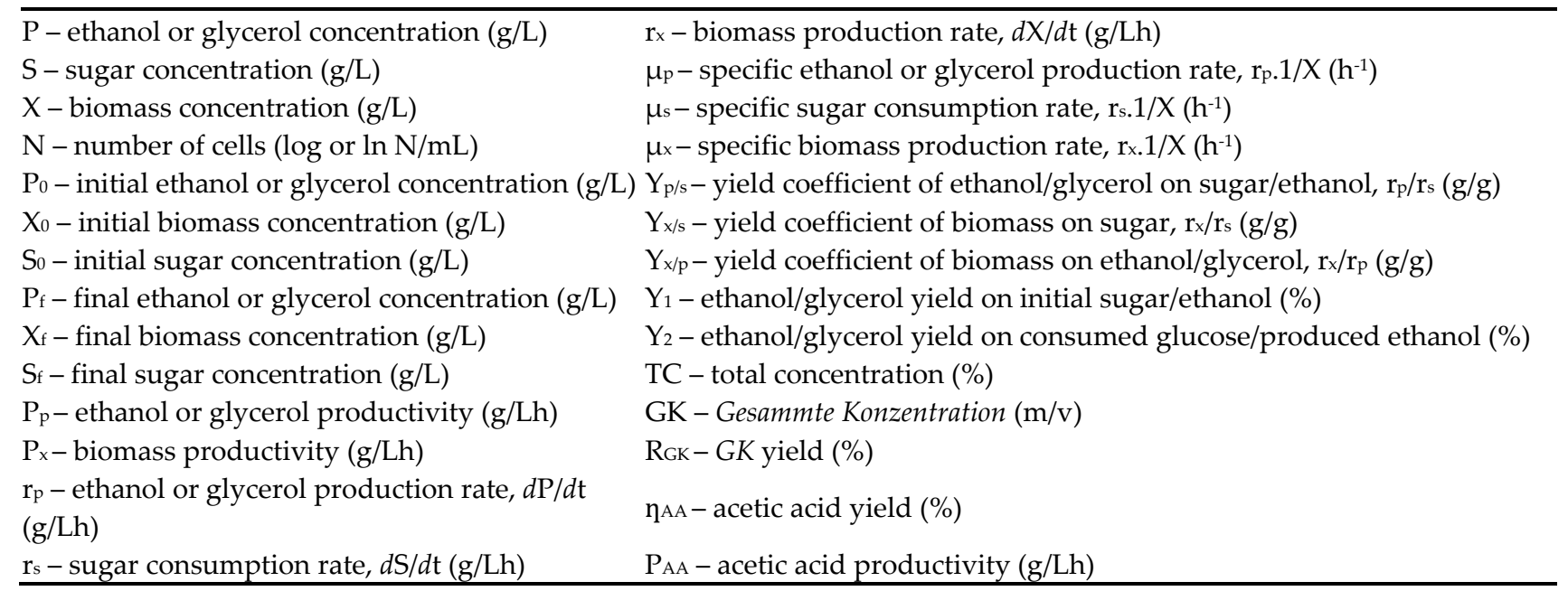

Conflict of interest: The authors have no conflicts of interest to declare.

Acknowledgements: The authors would like to thank the State University of Londrina (UEL) and CAPES for their scholarship.

\section{References}

1. Carvalho, G. B. M., Silva, D. P., Bento, C. V., Vicente, A. A., Teixeira, J. A., Felipe, M. G. A., Silva, J. B. A. Banana as adjunct in beer production: Applicability and performance of fermentative parameters. Appl. Biochem. Biotechnol. 2009, 155, 356-365.

2. Alvarenga, R. M., Carrara, A. G., Silva, C. M., Oliveira, E. S. Pottencial application of Saccharomyces cerevisiae strains for the fermentation of banana pulp. Afr. J. of Biotechnol. 2011, 10, 3608-3615.

3. Spinosa, W. A., Santos, V. Jr., Galvan, D., Fiorio, J. L., Gomez, R. J. H. C. Fermentation kinetics of rice syrup, with high content of dextrose equivalent, by Saccharomyces cerevisiae and characterization of volatile compounds from wine. J. Food Process. Pres. 2016. <doi:10.1111/jfpp.12702>

4. Spinosa, W. A., Santos, V., Jr., Galvan, D., Fiorio, J. L., Gomez, R. J. H. C. Vinegar rice (Oryza sativa L.) produced by a submerged fermentation process from alcoholic fermented rice. Food Sci. Technol. Campinas. 2015, 35, 196-201.

5. Parrondo, J., Herrero, M., García, L. A., Díaz, M. A note - Production of vinegar from whey. J. Inst. Brew. 2003, 109, 356-358.

6. Tessaro, D., Larsen, A. C., Dallago, R. C., Damasceno, S. G., Sene, L., Coelho S. R. M. Alcohol and acetic fermentation appraisal for vinegar production from orange juice. Acta Sci. Technol. 2010, 32, 201-205.

7. Siqueira, P. F., Karp, S. G., Carvalho, J. C., Sturm, W., Rodríguez-León, J. A., Tholozan, J. L., Singhania, R. R., Pandey, A., Soccol, C. R. Production of bio-ethanol from soybean molasses by Saccharomyces cerevisiae at laboratory, pilot and industrial scales. Bioresource Techonol. 2008, 99, 8156-8163.

8. Wills, R., McGlasson, B., Graham, D., Joyce, D. Postharvest: An introduction to the physiology and handling of fruits vegetables \& ornamentals, 4th ed.; UNSW Press: Sydney, 1998.

9. A.O.A.C. Association of Official Analytical Chemists. Official methods of analysis, 19th ed.; AOAC International: Virginia, 2012.

10. DuBois, M., Gilles, K. A., Hamilton, J. K., Rebers, P. A., Smith F. Colorimetric method form determination of sugars and related substances. Anal. Chemi. 1956, 28, 350-356.

11. A.P.H.A. American Public Health Association. Standard Methods for the Examination of Water and Wastewater, 20th ed.; APHA-AWWA-WEF: Washington, 1998.

12. C.T.C. Centro de Tecnologia Canavieira. Manual de métodos analíticos controle químico da fermentação, 2nd ed.; CTC: Piracicaba, 2011. 
13. McGowan, M. W., Artiss, J. D., Strandbergh, D. R., Zak, B. A peroxidase-coupled method for the colorimetric determination of serum triglycerides. Clin. Chem. 1983, 29, 538-542.

14. Bortoleto, A. M., Alcarde, A. R. Congeners in sugar cane spirits aged in casks of different woods. Food Chem. 2013, 15, 695-701.

15. Brazil, 2005. Ministério da Agricultura, Pecuária e Abastecimento, M.A.P.A. MET LABV-04-05 Determinação de acidez volátil. Instrução Normativa $n^{\underline{0}} 24$, 08.09.2005. Avaliable at: http://www.agricultura.gov.br/arq_editor/file/Aniamal/Laborat\%C3\%B3rios/Metodos\%20IQA/BEV/Lana gros/MET\%20LABV-04-05\%20Determinacao\%20de\%20acidez\%20volatil.pdf, Accessed 10 november 2015.

16. Wall, M. M. Ascorbic acid, vitamin A and mineral composition of banana (Musa sp.) and papaya (Carica papaya) cultivars grown in Hawaii. J. Food Compos. Anal. 2006, 19, 434-445.

17. Wang, Z., Zhuge, J., Fang, H., Prior, B. A. Glycerol production by microbial fermentation: A review. Biotechnol. Adv. 2001, 19, 201-223.

18. Arruda, A. R., Casimiro, A. R. S., Garruti, D. S., Abreu, F. A. P. Physical-chemical characterization and sensory evaluation of a fermented alcoholic beverage of banana. Rev. Ciên. Agron. 2007, 38, 37-384.

19. Akubor, P. I., Obio, S. O., Nwadomere, K. A., Obiomah, E., Production and quality evaluation of banana wine. Plant. Food. Hum. Nutr. 2003, 58, 1-6.

20. Versari, A., Laurie, V. F., Ricci, A., Laghi, L., Parpinello, G. P. Progress in authentication, typification and traceability of grapes and wines by chemometric approaches. Food Res. Int. 2014, 60, 2-18.

21. Reddy, L. V., Reddy, Y. H. K., Reddy, L. P. A., Reddy, O. V. S. Wine production by novel yeast biocatalyst prepared by immobilization on watermelon (Citrullus vulgaris) rind pieces and characterization of volatile compounds. Process. Biochem. 2008, 43, 748-752.

22. Navarro, A. R. Effects of furfural on ethanol fermentation by Saccharomyces cerevisiae: mathematical models. Curr. Microbiol. 1994, 29, 87-90.

23. Taherzadeh, M. J., Gustafsson, L., Niklasson, C., Lidén, G. Conversion of furfural in aerobic and anaerobic batch fermentation of glucose by Saccharomyces cerevisiae. J. Biosci. Bioeng. 1999, 87, 169-174.

24. Cheirsilp, B., Umsakul, K. Processing of banana-based wine product using pectinase and $\alpha$-amylase. J. Food Process. Eng. 2008, 31, 78-90.

25. Mohapatra, D., Mishra, S., Singh, C. B., Jayas, D. S. Post-harvest processing of banana: opportunities and challenges. Food Bioprocess Tech. 2011, 4, 327-339.

26. Thomas, D. E., Surdin-Kerjan, Y. Metabolism of sulfur amino acids in Saccharomyces cerevisiae. Microbiol. Mol. Biol. R. 1997, 61, 503-532.

27. Silva, M. E., Torres Neto, A. B., Silva, W. B., Silva, F. L. H., Swarnakar, R. Cashew wine vinegar production: Alcoholic and acetic fermentation. Braz. J. Chem. Eng. 2007, 24, 163169.

28. Bortolini, F., Sant'Anna, E. S., Torres, R. C. Comportamento das fermentações alcoólica e acética de sucos de kiwi (Actinidia deliciosa); composição dos mostos e métodos de fermentação acética. Ciênc. Tecnol. Aliment. Campinas. 2010, 21, 236-243.

29. Marques, F. P. P., Spinosa, W., Fernandes, K. F., Castro, C. F. S., Caliari, M. Quality pattern and identity of commercial fruit and vegetable vinegar (Acetic acid fermentation). Ciênc. Tecnol. Aliment. Campinas. 2010, 30, 119-126.

30. Parmar, I., Rupasinghe, H. P. V. Bio-conversion of apple pomace into ethanol and acetic acid: Enzymatic hydrolysis and fermentation. Bioresource Technol. 2013, 130, 613-620.

31. Brazil, 2012. Ministério da Agricultura, Pecuária e Abastecimento, M.A.P.A. Instrução Normativa $n^{\circ} 06$, 03.04.2012. Estabelece os padrões de identidade e qualidade e a classificação dos fermentados acéticos. Diário Oficial da União, Poder Executivo, Brasília, DF, 03.04.2012, Seção 1, p. 17.

32. Morales, M. L., Tesfaye, W., García-Parrilla, M. C., Casas, J. A., Troncoso, A. M. Evolution of the aroma profile of sherry wine vinegars during an experimental aging in wood. J. Agric. Food Chem. 2002, 50, 31733178.

33. Reddy, L. V. A., Kumar, Y. S., Reddy, O. V. S. Analysis of volatile aroma constituents of wine produced from Indian mango (Mangifera indica L.) by GC-MS. Ind. J. Microbiol. 2010, 50, 183-191.

(C) 2016 by the authors; licensee Preprints, Basel, Switzerland. This article is an open access article distributed under the terms and conditions of the Creative Commons by Attribution (CC-BY) license (http://creativecommons.org/licenses/by/4.0/). 